The $3{ }^{\text {rd }}$ Conf. of SSFOP "Recent Techniques in Ornamental Plants Scope", Cairo, Egypt, 26/2/2017

Scientific J. Flowers \& Ornamental Plants

www.ssfop.com/journal

ISSN: 2356-7864

\title{
EFFECT OF GROWING MEDIA AND FERTILIZATION TREATMENTS ON GROWTH AND FLOWERING OF GARDENIA JASMINOIDES PLANTS
}

\author{
F.S. Badran ${ }^{*}$, M.A. Abdou*, A.A. El-Sayed ${ }^{*}$, Boshra A. El-Sayed ${ }^{* *}$ and A.A. Gohar ${ }^{* *}$ \\ * Fac. Agric., Minia Univ., Egypt. \\ ** Ornamental Plants and Landscape Gardening Res. Dept., Hort. Res. Inst., ARC, Giza, Egypt.
}

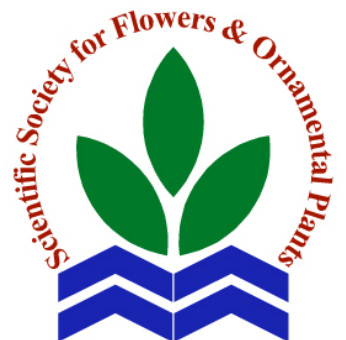

Scientific J. Flowers \& Ornamental Plants, 4(1):131-141 (2017).

Received: 5/1/2017

Accepted: 24/1/2017

ABSTRACT: The effect of three growing media types (peatmoss, peatmoss + sand and peatmoss + sand clay) and five fertilization treatments (control, mineral NPK, humic acid, EM and humic acid + EM) on growth and flowering of Gardenia jasminodies was investigated during two successive seasons of 2014 and 2015 under greenhouse conditions..

The peatmoss growing medium was superior to the other media types in increasing plant height, stem diameter, branch and leaf number/plant, leaves and roots dry weights/ plant, as well as, number and fresh weights of flowers/plant and in producing earlier flowering. In the second place came peatmoss + sand, while peatmoss + sand+ clay gave the least values of all these traits and produced the most delayed flowers of Gardenia.

Concerning fertilization treatments, the combined treatment of humic acid plus EM produced the best vegetative and flowering characters. Like that of NPK treatment, while each of humic acid or EM alone gave less values. Moreover, the three tested treatments of humic acid and/or EM caused early flowering date while NPK produced late flowering in comparison with untreated plants.

The overall best vegetative growth and flowering aspects in addition to early flowering date were given due to planting Gardenia jasminoides plants in peatmoss or peatmoss plus sand and fertilizing them with humic acid plus EM.

Key words:Gardenia jasminoides, growing media, humic acid, effective microorganisms (EM), NPK, vegetative growth, flowering.

\section{INTRODUCTION}

Gardenia jasminoides, Ellis is an evergreen shrus $60-150 \mathrm{~cm}$ tall, characterized with glossy, bright green leaves and large double white highly fragrant flowers. Such plant grows successfully outdoors and indoors as a pot plant, as well. It requires rich, moist, well drained acidic soil (pH 5.0 - 5.5). As an indoor pot plant, it should receive plenty of bright light, preferably direct sunshine for at least half a day in a sunny South or West window. The most suitable temperature is about $12{ }^{\circ} \mathrm{C}$ at night and $25-25{ }^{\circ} \mathrm{C}$ during the day with a uniform moisture and good drainage in the growth medium, (Kobayashi and Kaufman, 2006).

The preferability of peatmoss or peatmoss plus some other additives (like sand or sand + clay) in growing many 


\section{F.S. Badran et al.}

ornamental pot plants with good vegetative growth and/or flowering characteristics was revealed by many authors such as Marfa et al. (2002) on Nerium oleander; Verhagen (2004) on 3 flowering plants; Ashour (2006) on Ficus elastica and Kalirana and Dubey (2008) and Basheer and Thekkayam (2012) on Anthurium. Similar findings were also reported by Abd-Elfattah et al. (2009) on Dracaena and Ruscus; Farhat Naz et al. (2013) on Antirrhinum majus and AbdulHafeez et al. (2015) and Mousa et al. (2015) on Gardenia jasminoides. Meanwhile, the role of mineral NPK in delaying flowering date but enhancing different vegetative growth and/or flowering parameters was indicated by Badran et al. (1989a) and Abdou (2002) on borage; Badran et al. (1989b) on calla; Sayed (2004) and Dongardive et al. (2007) on Gladiolus; Ashour (2006) on Ficus elastica and Badran et al. (2008) on Koelreuteria paniculata. Some other investigators proved the efficient role of humc acid such as Evans and $\mathrm{Li}$ (2003) on four ornamental plants, Azzaz et al. (2007) on pot marigold; El-Sayed and ElShal (2008) on Schefflera; Abd-Elfattah et al. (2009) on Dracaena and Ruscus; ElSayed et al. (2010) on Bougainvillea glabra; Ahmad et al. (2013) on Gladiolus and Yukun et al. (2014) on Gazania. However, the stimulative influence of EM was pointed out by Thach et al. (1999) on orchid; AbdElraoof (2009) on borage; Hassanein and ElSayed (2009) and Ahmed (2013) on Glaidolus; Ashour (2010) on jojoba; Romualad and Tomaz (2010) on Gerbera; Ali (2013) on pot marigold and Yukun et al. (2014) on Gazania.

Such trial aimed to find out the most suitable growing media, fertilization treatment, as well as, the best combined treatment between both factors for producing good quality Gardenia jasminoides pot plant.

\section{MATERIALS AND METHODS}

This trial was carried out during 2014 and 2015 successive seasons in the greenhouse of the Floriculture Res. Dept., Hort. Res. Institute, Giza, Egypt to find out the most suitable growing media, fertilization treatment and their combination for producing the best growth and flowering of Gardenia jasminodies, Ellis pot plants.

Rooted cutting of Gardenia with overage height of $5 \mathrm{~cm}$, were obtained from Safwat Habib Nursery, Giza, and were transplanted on the first week of March for both seasons in $20 \mathrm{~cm}$ diameter plastic pots and were placed in desert airconditioned fiberglass greenhouse. These plastic pots were filled with one of the three tested growing media types (peatmoss, peatmoss + sand $(1: 1 \mathrm{v} / \mathrm{v})$ or peatmoss+ sand + clay $(1: 1: 1 \mathrm{v} / \mathrm{v} / \mathrm{v})$. Average total weight for the growing media, including the plastic pots was 1050, 1400 and 1770 g, respectively. After transplanting, Mooncut (a fungiside) was added to all plants as soil drench. Also, all plants were foliar sprayed with chelated ferrous at the rate of $150 \mathrm{ppm}$ every month along the growing season. The experimental layout of this trial was complete randomized block design in factorial arrangement with three replicates and five plants/replicate. The main plots included the three previously mentioned growing media, while the subplots represented five fertilization treatments, namely control, mineral NPK (Kristalon, 10:10:19), humic acid $(\mathrm{H})$, effective microorganisms(EM) and $\mathrm{H}+$ EM. Kristalon was added at the rate of $2.0 \mathrm{~g} /$ pot every 2 weeks, while humic acid and EM were applied at the rate of $5 \mathrm{~cm}^{2} / 1$ and $1 \mathrm{~cm}^{3} / \mathrm{l}$, respectively, every 2 weeks, as soil drench, starting one week after transplanting.

Physical and chemical properties of the used sand and loam (Table, a) and peatmoss (Table, b) in the two seasons are illustrated.

One month after the last fertilization dose, on the first week of Oct. for both seasons, vegetative growth characters were recorded such as plant height $(\mathrm{cm})$, stem diameter $(\mathrm{mm})$, number of main branches/plan, number of leaves/plant, leaves dry weigh/plant (g) and roots dry weight/plant (g). In addition, flowering parameters such as flowering date, as number of days from transplanting to the 
Table a. Physical and chemical properties of sand and loam.

\begin{tabular}{lcccc}
\hline \multirow{2}{*}{ Properties } & \multicolumn{2}{c}{ Sand } & \multicolumn{2}{c}{ Loam } \\
& $\mathbf{1}^{\text {st }}$ & $\mathbf{2}^{\text {nd }}$ & $\mathbf{1}^{\text {st }}$ & $\mathbf{2}^{\text {nd }}$ \\
\hline Coarse sand (\%) & 89.03 & 90.10 & 10.18 & 10.80 \\
Fine sand (\%) & 2.05 & 1.95 & 46.17 & 46.54 \\
Silt (\%) & 0.40 & 0.50 & 19.53 & 18.88 \\
Clay (\%) & 8.52 & 7.45 & 24.12 & 24.28 \\
$\mathbf{E C ~ ( d S / m ) ~}$ & 3.56 & 3.71 & 3.48 & 3.36 \\
$\mathbf{p H}$ & 7.90 & 7.80 & 8.27 & 7.96 \\
$\mathbf{C a}^{++}$(meq/l) & 7.50 & 19.42 & 17.50 & 18.00 \\
$\mathbf{M g}^{++}$(meq/l) & 1.63 & 8.33 & 9.42 & 8.95 \\
$\mathbf{~ N a}^{+}$(meq/l) & 33.60 & 7.20 & 20.00 & 20.50 \\
$\mathbf{K}^{+}$(meq/l) & 0.50 & 0.75 & 0.79 & 0.85 \\
$\mathbf{H C O}_{\mathbf{3}}^{-}$(meq/l) & 3.20 & 1.60 & 3.80 & 3.65 \\
$\mathbf{C l}^{-}$(meq/l) & 22.00 & 7.00 & 10.00 & 10.20 \\
SO $_{\mathbf{4}}^{-}$(meq/l) & 18.03 & 27.10 & 33.91 & 34.25 \\
\hline
\end{tabular}

Table b. Physical and chemical properties of the used peatmoss in the two seasons.

\begin{tabular}{|c|c|c|c|}
\hline Properties & Values & Properties & Values \\
\hline Org. Matter (\%) & $90-95$ & $P(\%)$ & 0.23 \\
\hline Ash (\%) & $8-10$ & K (\%) & 1.77 \\
\hline $\begin{array}{l}\text { Density (Vol D.W. } \\
\text { mg/l) }\end{array}$ & $80-90$ & Fe (ppm) & 421.0 \\
\hline pH & 3.4 & Mn (ppm) & 27.0 \\
\hline $\begin{array}{l}\text { Water retention } \\
\text { cap. }(\%)\end{array}$ & $60-75$ & Zn (ppm) & 41.0 \\
\hline Salinity (mg/l) & 0.3 & Cu (ppm) & 8.8 \\
\hline N (\%) & 1.09 & Mg (ppm) & 3.3 \\
\hline
\end{tabular}

burst of flowering buds, number of flowers/ plant and flowers fresh weight/plant (g) were registered. All other agricultural practices were followed as usual. All vegetative growth characters and flowering parameters were statistically analyzed according to Little and Hills (1978).

\section{RESULTS AND DISCUSSION}

\section{Vegetative growth characters:}

Tables (1 and 2) show that the six vegetative growth characters, studied in the present trial, were increased, in both seasons, due to the use of peatmoss over the other two growing media types, followed by peatmoss + sand. However, the triple growing media (peatmoss + sand + clay) gave the least values. The differences between peatmoss and peatmoss + sand + clay growing media types were significant in both seasons for plant height, number of leaves/plant and dry weight of leaves and roots/plant as indicated in Tables (1 and 2). The preferability of peatmoss was revealed by Abdul-Hafeez et al. (2015) and Mousa et al. (2015) on Gardenia jasminoides; Marfa et al. (2002) on Nerium oleander; Verhagen (2004) on three flowering plants; Ashour (2006) on Ficus elsatica and Kalirana and Dubey (2008) and Basheer Thekkayam (2012) on Anthurium. Similar findings were reported by Abd-Elfattah et al. (2009) on Dracaena and Ruscus and Farhat Naz et al. (2013) on Anthirrhinum majus.

Concerning fertilization treatments, all of them, in both seasons, caused significant increase in plant height, stem diameter, number of branches and leaves/plant and dry weight of leaves and roots/plant in comparison with those of untreated plants as shown in Tables (1 and 2). It was interesting to note that the treatment of humic acid plus EM gave equal values, for stem diameter, number of branches and leaves/plant and dry weight of leaves and roots/plant, to those recorded for the NPK treatment, but to overgrew the NPK treatment concerning plant height. It was noticed also that the combined treatment of humic acid/EM was much more effective than each of humic acid or EM alone for all tested vegetative growth characters, (Tables 1 and 2). The role of NPK in augmenting vegetative growth traits was observed on borage (Badran et al., 2989a and Abdou, 2002); calla (Badran et al., 1989b); Gladiolus (Sayed, 2004); Ficus elastica (Ashour, 2006) and Koelreuteria paniculata (Badran et al., 2008). What of humic acid was found out on pot marigold (Azzaz et al, 2007); Schefflera (El- Sayed and El-Shal, 2008); Dracaena and Ruscus (Abd-Elfattah et al., 2009). Bougainvillea glabra (El-Sayed et al., 2010) and Gazania (Yukun et al., 2014). Meanwhile, the effectiveness of EM in promoting vegetative growth was obtained on orchid (Thach et al., 
Table 1. Effect of growing media and fertilization treatments on vegetative growth of Gardenia jasminoides during 2014 and 2015 seasons.

\begin{tabular}{|c|c|c|c|c|c|c|c|c|c|c|c|}
\hline \multirow{3}{*}{$\begin{array}{l}\text { Fertilization } \\
\text { Trts. (B) }\end{array}$} & \multicolumn{11}{|c|}{ Growing media type (A) } \\
\hline & & Peat & & & $\mathbf{P}+\mathbf{S}+\mathbf{C}$ & Mean B & & Peat & $\mathbf{P}+\mathbf{S}$ & $\mathbf{P}+\mathbf{S}+\mathbf{C}$ & Mean B \\
\hline & \multicolumn{6}{|c|}{ First season } & \multicolumn{5}{|c|}{ Second season } \\
\hline \multicolumn{12}{|c|}{ Plant height (cm) } \\
\hline Control & & 32.8 & \multicolumn{2}{|c|}{29.0} & 24.8 & 28.9 & & 30.6 & 25.6 & 21.7 & 26.0 \\
\hline NPK & & 36.6 & \multicolumn{2}{|c|}{33.6} & 28.5 & 32.9 & & 34.0 & 31.9 & 26.6 & 30.8 \\
\hline Humic acid (H) & & 48.1 & \multicolumn{2}{|c|}{46.3} & 35.6 & 43.3 & & 44.2 & 41.4 & 33.0 & 39.5 \\
\hline EM & & 49.3 & \multicolumn{2}{|c|}{45.8} & 34.8 & 43.3 & & 43.8 & 40.6 & 32.4 & 38.9 \\
\hline $\mathbf{H}+\mathbf{E M}$ & & 48.7 & \multicolumn{2}{|c|}{46.1} & 33.9 & 42.9 & & 43.0 & 39.3 & 32.7 & 38.3 \\
\hline Mean A & & 43.1 & \multicolumn{2}{|c|}{40.2} & 31.5 & & & 39.1 & 35.8 & 29.3 & \\
\hline LSD $5 \%$ & A & 2.3 & B & 2.8 & $\mathrm{AB}$ & 4.8 & A & 2.6 & В 2.8 & $\mathrm{AB}$ & 4.8 \\
\hline \multicolumn{12}{|c|}{ Stem diameter (mm) } \\
\hline Control & & 4.62 & \multicolumn{2}{|c|}{4.53} & 4.38 & 4.51 & & 4.25 & 4.12 & 4.07 & 4.15 \\
\hline NPK & & 5.82 & \multicolumn{2}{|c|}{5.77} & 5.58 & 5.72 & & 5.63 & 5.59 & 5.48 & 5.57 \\
\hline Humic acid (H) & & 5.11 & \multicolumn{2}{|c|}{5.09} & 4.91 & 5.04 & & 4.92 & 4.74 & 4.60 & 4.75 \\
\hline EM & & 5.08 & \multicolumn{2}{|c|}{5.13} & 4.88 & 5.03 & & 4.88 & 4.80 & 4.62 & 4.77 \\
\hline $\mathbf{H}+\mathbf{E M}$ & & 5.66 & \multicolumn{2}{|c|}{5.56} & 5.46 & 5.56 & & 5.58 & 5.49 & 5.35 & 5.47 \\
\hline Mean A & & 5.26 & \multicolumn{2}{|c|}{5.22} & 5.04 & & & 5.05 & 4.95 & 4.82 & \\
\hline LSD $5 \%$ & A & N.S. & B & .30 & $\mathrm{AB}$ & 5.2 & A & N.S. & В .25 & $\mathrm{AB}$ & 4.3 \\
\hline & & & & Nur & ber of main & branches & $/$ pla & & & & \\
\hline Control & & 3.28 & & 18 & 3.12 & 3.19 & & 3.51 & 3.39 & 3.32 & 3.41 \\
\hline NPK & & 4.94 & & 88 & 4.72 & 4.85 & & 4.72 & 4.61 & 4.48 & 4.60 \\
\hline Humic acid (H) & & 4.36 & & 32 & 4.29 & 4.32 & & 4.25 & 4.26 & 4.06 & 4.19 \\
\hline EM & & 4.44 & & 26 & 4.16 & 4.29 & & 4.16 & 4.08 & 4.04 & 4.09 \\
\hline $\mathbf{H}+\mathbf{E M}$ & & 4.88 & & 69 & 4.55 & 4.71 & & 4.54 & 4.46 & 4.43 & 4.48 \\
\hline Mean A & & 4.38 & & 27 & 4.21 & & & 4.24 & 4.16 & 4.07 & \\
\hline LSD $5 \%$ & A & N.S. & B & .28 & $\mathrm{AB}$ & 4.8 & A & N.S. & В .24 & $\mathrm{AB}$ & 4.2 \\
\hline
\end{tabular}

EM= Effective microorganisms. 
Table 2. Effect of growing and fertilization treatments on vegetative growth of Gardenia jasminoides during 2014 and 2015 seasons.

\begin{tabular}{|c|c|c|c|c|c|c|c|c|c|c|c|c|}
\hline \multirow{3}{*}{$\begin{array}{l}\text { Fertilization } \\
\text { Trts. (B) }\end{array}$} & \multicolumn{12}{|c|}{ Growing media type (A) } \\
\hline & \multirow{2}{*}{\multicolumn{2}{|c|}{ Peat }} & \multirow{2}{*}{\multicolumn{3}{|c|}{$\begin{array}{c}\mathbf{P}+\mathrm{S} \quad \mathrm{P}+\mathrm{S}+\mathrm{C} \\
\text { First season }\end{array}$}} & \multirow[t]{2}{*}{ Mean B } & \multirow{2}{*}{\multicolumn{2}{|c|}{ Peat }} & \multirow{2}{*}{\multicolumn{3}{|c|}{$\begin{array}{l}\mathbf{P}+\mathbf{S} \quad \mathbf{P}+\mathrm{S}+\mathrm{C} \\
\text { Second season }\end{array}$}} & \multirow[t]{2}{*}{ Mean B } \\
\hline & & & & & & & & & & & & \\
\hline \multicolumn{13}{|c|}{ Number of leaves/plant } \\
\hline Control & \multicolumn{2}{|c|}{53.3} & \multicolumn{2}{|c|}{51.9} & 48.2 & 51.1 & \multicolumn{2}{|c|}{51.8} & \multicolumn{2}{|c|}{50.2} & 45.0 & 49.0 \\
\hline NPK & \multicolumn{2}{|c|}{70.2} & \multicolumn{2}{|c|}{68.4} & 62.7 & 67.1 & \multicolumn{2}{|c|}{66.6} & \multicolumn{2}{|c|}{64.4} & 61.5 & 64.2 \\
\hline Humic acid (H) & \multicolumn{2}{|c|}{46.5} & \multicolumn{2}{|c|}{63.1} & 58.8 & 62.1 & \multicolumn{2}{|c|}{61.9} & \multicolumn{2}{|c|}{59.3} & 57.1 & 59.4 \\
\hline EM & \multicolumn{2}{|c|}{46.9} & \multicolumn{2}{|c|}{62.6} & 57.0 & 62.5 & \multicolumn{2}{|c|}{62.3} & \multicolumn{2}{|c|}{58.8} & 55.7 & 58.9 \\
\hline $\mathbf{H}+\mathbf{E M}$ & \multicolumn{2}{|c|}{71.9} & \multicolumn{2}{|c|}{68.6} & 62.0 & 67.5 & \multicolumn{2}{|c|}{65.8} & \multicolumn{2}{|c|}{62.9} & 60.5 & 63.1 \\
\hline Mean A & & 5.0 & & 2.9 & 57.7 & & & 61.7 & & 9.1 & 56.0 & \\
\hline LSD $5 \%$ & A & 3.8 & B & 3.4 & $\mathrm{AB}$ & 5.9 & A & 3.0 & B & 2.6 & $\mathrm{AB}$ & 4.5 \\
\hline & & & & & aves dry w & eight/plaı & t (g) & & & & & \\
\hline Control & & 46 & & .13 & 5.08 & 5.22 & & 5.05 & & .88 & 4.62 & 4.85 \\
\hline NPK & & 60 & & .42 & 6.85 & 7.29 & & 7.31 & & .15 & 6.84 & 7.10 \\
\hline Humic acid (H) & & 89 & & .74 & 6.41 & 6.68 & & 6.80 & & .83 & 6.33 & 6.65 \\
\hline EM & & 92 & & .70 & 6.33 & 6.65 & & 6.92 & & .88 & 6.42 & 6.74 \\
\hline $\mathbf{H}+\mathbf{E M}$ & & 52 & & .36 & 6.81 & 7.23 & & 7.24 & & .09 & 6.81 & 7.05 \\
\hline Mean A & & 88 & & 67 & 6.30 & & & 6.66 & & .57 & 6.20 & \\
\hline LSD $5 \%$ & A & 0.42 & B & 0.54 & $\mathrm{AB}$ & 0.93 & A & 0.37 & B & 0.42 & $\mathrm{AB}$ & 0.73 \\
\hline & & & & & ots dry we & ight/plan & (g) & & & & & \\
\hline Control & & 34 & & 12 & 3.36 & 3.94 & & 4.11 & & .87 & 2.88 & 3.61 \\
\hline NPK & & .97 & & 82 & 3.89 & 4.56 & & 4.77 & & .62 & 3.74 & 4.34 \\
\hline Humic acid (H) & & 52 & & 32 & 3.67 & 4.17 & & 4.35 & & .15 & 2.96 & 3.82 \\
\hline EM & & 46 & & 39 & 3.69 & 4.18 & & 4.41 & & .08 & 2.98 & 3.82 \\
\hline $\mathbf{H}+\mathbf{E M}$ & & 92 & & .76 & 3.82 & 4.50 & & 4.72 & & .60 & 3.69 & 4.34 \\
\hline Mean A & & 66 & & .78 & 3.69 & & & 4.47 & & .26 & 3.25 & \\
\hline LSD $5 \%$ & A & 0.24 & B & 0.20 & $\mathrm{AB}$ & 0.35 & A & 0.33 & B & 0.26 & $\mathrm{AB}$ & 0.45 \\
\hline
\end{tabular}

EM= Effective microorganisms. 


\section{F.S. Badran et al.}

1999); borage (Abd-Elraoof, 2009); Gladiolus (Hassanien and El-Sayed , 2009 and Ahmed, 2013); jojoba (Ashour, 2010) and pot marigold (Ali, 2013).

The interaction between growing media types and fertilization treatments was significant, in both seasons, for the six vegetative growth characters as shown in Tables (1 and 2). The tallest plants were due to growing Gardenia plants in peatmoss and supplying them with humic acid, EM or humic acid/EM. However, the thickest stems, the highest number of main branches and leaves/plant and the heaviest leaves and roots dry weights of such investigated plants were obtained due to the use of peatmoss along the supplement of either NPK or humic acid EM fertilization treatments, (Table 1 and 2).

\section{Flowering parameters:}

In regard to growing media, peatmoss caused significantly early flowering and produced significantly the highest flower number/plant and the heaviest flowers fresh weight/plant, in both seasons, in comparison with the other two growing media types (peatmoss + sand and peatmoss + sand + clay) as illustrated in Table (3). The latest flowering date and the least flower number and flowers fresh weight/plant were given by the triple growing media, while, peatmoss + sand gave intermediate values in this concern. The capability of peatmoss in causing early flowering and increasing flower number and weight/plant was obtained by Abdul-Hafeez et al. (2015) and Mousa (2015) on Gardenia jasminoides; Marfa et al. (2002) on oleander; Verhagen (2004) on three flowering plants; Kalirana and Dubey (2008) and Basheer and Thekkayam (2012) on Anthurium and Farhat Naz et al. (2013) on Antirrhinum majus.

In relation to fertilization treatments, NPK caused significant delaying in flowering date, while humic acid, EM and humic acid/EM treatments produced significantly early flowering, in the first and second seasons, in comparison with control treatment. Concerning number of flowers/ plant and flowers fresh weigh/plant, both traits were dramatically and significantly raised, in both seasons, due to NPK, humic acid, EM and humic acid/EM treatments over those of control treatment. Among such four treatments, NPK and humic acid/ EM treatments were superior to the other two ones (humic acid and EM) with nonsignificant differences between NPK and humic acid/ EM in both seasons as clearly shown in Table (3). The role of NPK in delaying flowering date but increasing flowers number and weight was mentioned by Badran et al. (1989a) and Abdou (2002) on borage; Badran et al. (1989b) on calla and Sayed (2004) and Dongardive et al. (2007) on Gladiolus. While that of humic acid in accelerating flowering date and augmenting number and weight of flowers was pointed out by Evans and Li (2003); Azzaz et al. (2007), Ahmad et al. (2013) and Yukun et al. (2014) on four ornamental plants, pot marigold, Gladiolus and Gazania, respectively. Similar positive effect of EM was emphasized by Thach et al. (1999) on orchid; Abd-Elraoof (2009) on borage; Hassanien and El-Sayed (2009) and Ahmed (2013) on Gladiolus; Romualad and Tomasz (2010) on Gerbera; Ali (2013) on pot marigold and Yukun et al. (2014) on Gazania.

The interaction between growing media types and fertilization treatments was significant, in the two seasons, for flowering date, number of flowers/plant and flowers fresh weight/plant. The earliest flowering was obtained when Gardenia was grown in peatmoss and fertilized with the combined treatment of humic acid/EM while the highest flower number/plant and the heaviest flowers fresh weight/ plant were due to using peatmoss in combination with either NPK or humic/EM, as clearly shown in Table (3).

It is convenient to discuss and explain the roles of the used growing media types 
Table 3. Effect of growing media and fertilization treatments on flowering parameters of Gardenia jasminoides during 2014 and 2015 seasons.

\begin{tabular}{|c|c|c|c|c|c|c|c|c|c|c|c|c|}
\hline \multirow{3}{*}{$\begin{array}{l}\text { Fertilization } \\
\text { Trts. (B) }\end{array}$} & \multicolumn{12}{|c|}{ Growing media type (A) } \\
\hline & \multirow{2}{*}{\multicolumn{2}{|c|}{ Peat }} & \multirow{2}{*}{\multicolumn{3}{|c|}{$\begin{array}{l}\mathrm{P}+\mathrm{S} \quad \mathrm{P}+\mathrm{S}+\mathrm{C} \\
\text { First season }\end{array}$}} & \multirow{2}{*}{ Mean B } & \multirow{2}{*}{\multicolumn{2}{|c|}{ Peat }} & \multirow{2}{*}{\multicolumn{3}{|c|}{$\begin{array}{l}\mathrm{P}+\mathrm{S} \quad \mathrm{P}+\mathrm{S}+\mathrm{C} \\
\text { Second season }\end{array}$}} & \multirow[t]{2}{*}{ Mean B } \\
\hline & & & & & & & & & & & & \\
\hline \multicolumn{13}{|c|}{ Flowering date (day) } \\
\hline Control & & 50.5 & & 7.8 & 62.7 & 57.0 & & 44.4 & & 0.5 & 56.6 & 50.5 \\
\hline NPK & & 0.3 & & 3.5 & 67.4 & 63.7 & & 57.0 & & 2.2 & 63.0 & 60.7 \\
\hline Humic acid (H) & & 40.8 & & 3.6 & 45.6 & 43.3 & & 36.1 & & 0.9 & 43.3 & 40.1 \\
\hline EM & & 42.2 & & 4.0 & 46.0 & 44.1 & & 35.8 & & 1.7 & 44.2 & 40.6 \\
\hline $\mathbf{H}+\mathbf{E M}$ & & 40.1 & & 3.1 & 46.0 & 43.1 & & 35.3 & & 8.8 & 42.8 & 39.0 \\
\hline Mean A & & 46.8 & & 0.4 & 53.5 & & & 41.7 & & 6.8 & 50.0 & \\
\hline LSD $5 \%$ & A & 3.0 & B & 4.1 & $\mathrm{AB}$ & 7.1 & A & 3.2 & B & 3.8 & $\mathrm{AB}$ & 6.6 \\
\hline \multicolumn{13}{|c|}{ Number of flowers/plant } \\
\hline Control & & 3.61 & & .08 & 2.39 & 3.03 & & 4.02 & & 54 & 3.06 & 3.54 \\
\hline NPK & & 3.35 & & .88 & 7.03 & 7.75 & & 8.40 & & 82 & 7.30 & 7.84 \\
\hline Humic acid (H) & & 7.80 & & .25 & 6.44 & 7.16 & & 7.74 & & 29 & 7.05 & 7.36 \\
\hline EM & & 7.62 & & .36 & 6.30 & 7.09 & & 7.66 & & 34 & 7.10 & 7.37 \\
\hline $\mathbf{H}+\mathbf{E M}$ & & 3.20 & & .87 & 6.64 & 7.57 & & 8.18 & & 75 & 7.39 & 7.77 \\
\hline Mean A & & 7.12 & & 69 & 5.76 & & & 7.20 & & 75 & 6.38 & \\
\hline LSD $5 \%$ & A & 0.36 & B & .47 & $\mathrm{AB}$ & 0.81 & A & 0.42 & B & 0.51 & $\mathrm{AB}$ & 0.88 \\
\hline \multicolumn{13}{|c|}{ Flower fresh weight/plant (g) } \\
\hline Control & & 10.3 & & 8.4 & 5.5 & 8.1 & & 11.7 & & .9 & 7.0 & 9.5 \\
\hline NPK & & 39.3 & & 4.1 & 24.8 & 32.7 & & 41.3 & & 4.9 & 26.2 & 34.1 \\
\hline Humic acid (H) & & 32.9 & & 7.6 & 18.2 & 26.2 & & 33.1 & & 8.3 & 20.4 & 27.3 \\
\hline EM & & 31.9 & & 7.8 & 17.3 & 25.7 & & 32.9 & & 8.0 & 20.1 & 2.0 \\
\hline $\mathbf{H}+\mathbf{E M}$ & & 38.3 & & 3.4 & 22.2 & 31.3 & & 38.8 & & 4.0 & 25.2 & 32.7 \\
\hline Mean A & & 30.5 & & 6.3 & 17.6 & & & 31.6 & & 7.0 & 19.8 & \\
\hline LSD $5 \%$ & A & 2.9 & B & 3.6 & $\mathrm{AB}$ & 6.2 & A & 3.4 & B & 3.7 & $\mathrm{AB}$ & 6.4 \\
\hline
\end{tabular}

EM= Effective microorganisms. 


\section{F.S. Badran et al.}

and fertilization treatments in enhancing vegetative growth characters and flowering parameters of Gadenia jasminoides plants. Concerning growing media, the best vegetative growth and flowering aspects were obtained due to the use of peatmoss followed by peatmoss + sand while the triple media (peatmoss + sand + clay) gave the least values. Peatmoss has been commonly used as a growing medium for container plant production. It has many advantages in terms of low $\mathrm{pH}$, high organic matter content, high water holding capacity and proper electrical conductivity. These properties help supply valuable water in adequate quantities for turgidity and enlargement of cells, consequently stimulates stem elongation and boosting plant growth. Moreover, the low $\mathrm{pH}$ of peatmoss positively influences plant growth through its effects on nutrient minerals availability and microbial activity. Gardenia plant prefers acidic soil ( $\mathrm{pH}$ 4.5-5.5) making it more susceptible to the increase in the growing medium $\mathrm{pH}$. The reduction in the $\mathrm{pH}$ affects the nutrients availability which directly affects vegetative growth characters and flowering aspects. In addition, peatmoss is characterized with a good texture and improves aeration which makes it possible for Gardenia roots to uptake nutrients and water, (Saleh, 2000 and Abdul-Hafez, 2003).

On the other side, sand faces many problems such as poor physical, chemical, microbial and nutritional properties, low water holding capacity and cation exchange capability, poor organic matter content, low level of available macro and micro nutrients and poor structure, but with good aeration (Aly, 1996). However, clay soil is characterized with the most desirable soil structure and soil texture, higher water holding capacity, better cation exchange capacity, higher organic matter content, adequate macro and micro nutrients readily available to plants and rich in beneficial microbial organisms, but lacking, relatively, to aeration and is much more compacted than sand or peatmoss for root penetration which might negatively affect vegetative growth and flowering (Kramer, 1969). Therefore, a balanced rooting medium that contains an adequate supply of nutrients, characterized with good soil physical and chemical properties and including adequate amounts of organic matter is the most suitable growing medium for attaining maximum plant growth and flowering of Gardenia jasminoides.

The beneficial roles of mineral NPK fertilization in enhancing vegetative growth and flowering of Gardenia plants could be explained via the physiological roles of each element in plant growth and development. Nitrogen is a constituent of all proteins, many enzymes and energy transfer materials such as chlorophyll, ADP and ATP. The severe shortage of nitrogen might halt the process of growth and reproduction (Bidwell, 1974). Phosphorus is essential for cell division and the development of meristimatic tissues and is very important for carbohydrate transformation due to multitude of phosphorylation reaction and to energy rich phosphate bond (Lambers et al., 2000). Phosphorus compounds are essential for photosynthesis, the interconvention of carbohydrates and related glycolysis, amino acid metabolism, fat metabolism and biological oxidation, (Devlin, 1972). Potassium is important for growth and elongation probably due to its function as an osmoticum and may react synergistically with IAA. It promotes $\mathrm{CO}_{2}$ assimilation and translocation of carbohydrates from the leaves to the storage tissues, (Mengel and Kirkby, 1987).

Humic acid is widely used, nowadays, for production of most crops including indoor container plants. It provides soil microbs with energy, increases the availability of nutrients in the soil through its influence on soil microbial activity, release more nutrients necessary for healthy growth. Moreover, humic acid was found to decrease phosphate fixing capacity of the soil, to improve nutrients retention in the soil, to 
enhance water holding capacity, to improve soil structure and to act as a source of $\mathrm{N}, \mathrm{P}$ and S for plants, (Higa and Widiana, 1991 and Dorer and Peacock, 1997). Concerning EM (effective microorganisms), it is a commercial Japanese product that contains more than 60 selected strains of effective microorganisms such as photosynthetic bacteria, lactic acid bacteria, yeast actinomytes and various fungi that improves growth and health of plants (Primavesi, 1999). It has been introduced to the organic farming system in many countries including Egypt. The use of EM led to larger stems, darker green leaves and accelerated flowering. It is also effective in creating humus and improving soil properties, increasing plant disease resistance and may play a role in enhancing the enzymatic system in the plant tissues and consequently enhancing growth (Thach, 1999 and Janas, 2009).

\section{REFERENCES}

Abd-Elfattah, G.H.; El-Sayed, B.A. and Khenizy, S.A. (2009). Response of Dracaena and Ruscus plants to humic acid and biofertilizer supply. Ann. of Agric. Sci., Moshtohor, 47 (1):111-119.

Abd-Elraoof, R.M. (2009). Response of Borage Plants to Some Organic and Biofertilization Treatment. Ph.D. Thesis, Fac. Agric., Minia Univ., Egypt.

Abdou, M.A. (2002). Influence of NPK and micronutrients on growth, flowering and chemical constituents of Borago officinalis, L. plants grown in sandy soil. Proc. Minia $1^{\text {st }}$ Conf. for Agric. \& Env. Sci., 22(2):1659-1672.

Abdul-Hafeez, E.Y. (2003). Response of Scindapsus aureus, L. Plants to Certain Growing Media and Fertilizers. M.Sc. Thesis, Hort. Dept., Fac. Agric., Assiut Univ.

Abdul-Hafeez, E.Y.; Ibrahim, O.H. and ElKeltawim, N.E. (2015). Reuse of wastewater from phosphate fertilizer factories can combat soil alkalinity and improve quality of potted gardenia Gardenia jasminoidies, Ellis). J. Biodiversity and Env. Sci., 6(3):423-433.

Ahmad, I.; Saquib, R.U.; Qasim, M. Salem, M.; Khan, A.S. and Yaseen, M. (2013). Humic acid and cultivar effects on growth, yield, vase life and corm characteristics of gladiolus. Chilean J. Agric. Res., 73:339-344.

Ahmed, A.S. (2013). Physiological Studies on Gladiolus Plant. M.Sc. Thesis, Fac. Agric., Minia Univ.

Ali, F.A. (2013). Effect of Organic and Biofertilization Treatments on Pot Marigold, Calendula officinalis, L., Plants. M.Sc. Thesis, Fac. Agric., Minia Univ., Egypt.

Aly, M.R. (1996). Evaluation of Sewage Sludge as an Amendment for Newly Reclaimed Soils. Ph.D. Thesis, Fac. Agric., Minia Univ.

Ashour, R.M. (2006). Physiological studies on the propagation of Ficus elastica var. Decora by Aerial Layering. M.Sc. Thesis, Fac. Agric., Minia Univ., Egypt.

Ashour, R.M. (2010). Response of Jojoba Plants to Some Organic and Biofertilization Treatments. Ph.D. Thesis, Fac. Agric., Minia Univ.

Azzaz, N.A.; Hassan, E.A. and El-Emary, F.A. (2007). Physiological, anatomical and biochemical studies on pot marigold (Calendula officinalis, L.) plants. African Crops Sci. Conf. Proc., Minia, Egypt, 8:1727-1738.

Badran, F.S.; Abdou, M.A.; Taha, R.A. and Ibrahim, S.I. (2008). Partial replacement of chemical fertilizers by biofertilizers in producing Koelreuteria paniculata seedlings. Proc. $1^{\text {st }}$ Inter. Conf. on Ornamental, Alex, J. of Agric. Res., 53(1):35-40.

Badran, F.S.; Aly, M.K. and Al-Badawy, A.A. (1989a). Effect of soil type and NP fertilization treatments on growth, flowering and chemical composition of 


\section{F.S. Badran et al.}

Borago officinalis, L. plants. Minia J. Agric. Res. \& Dev., 11(3):1073-1091.

Badran, F.S.; Al-Badawy, A.A. and Aly, M.K. (1989b). Effect of NPK fertilization treatments and spacing on the growth and flowering of Zantedeschia aethiopica, Spring. Minia J. Agric. Res. \& Dev., 11(3):525-535.

Basheer, S.N. and Thekkayam, S.G. (2012). Effect of growing media and organic nutrition on vegetative growth of Anthurium plants (Anthurium andreanum cv. Tropical). Asian J. of Hort., 7(2):354358.

Bidwell, R.G. (1974). Plant Physiology, Macmillan Co. Inc. New York, U.S.A.

Devlin, R.M. (1972). Plant Physiology, Third Edit., Van Nostrand Co., New York, U.S.A.

Dongardive, S.B.; Golliwar, V.J. and Bhongle, S.A. (2007). Effect of organic manure and biofertilizers on growth and flowering of gladiolus cv. White Prosperity. Plant Archives, 7(2):657-658.

Dorer, S.P. and Peacock, C.H. (1997). The effect of humate and organic fertilizer on establishment and nutrition of creeping bentgrass putting greens. Inter. Turfgrass Soc. Res. J., 8:437-443.

El-Sayed, B.A.; Ahmed, S.S. and Shahin, S.M. (2010). Effect of biofertilizer, humic acid, IBA and their interactions on rooting of some ornamental plants. II Paper flower (Bougainvillea glabra, Choicy,), Egypt. J. Appl. Sci., 25(8A):497-507.

El-Sayed, B.A. and El-Shal, S.A. (2008). Effect of growing media and humic acid on Scheffera quality. J. Agric. Sci., Mansorua Univ., 33(1):371-381.

Evans, M. and Li, G. (2003). Effect of humic acid on growth of annual ornamental seedling plugs, Horttechnology, 13(4):661-665.

Farhat Naz, Jalal-ud- Duin, B.; Munir, M. and Khakwani, A.A. (2013). Growth and development response of Antirrhinum to plant growing media. J. of Appl. Hort., 15(1):32-37.

Hassanien, M.M. and El-Sayed, S.G. (2009a). Effect of some organic and biofertilization treatments on gladiolus plants. I. Vegetative growth and flowering. J. Agric. Sci., Mansoura Univ., 34 (6): 6237-6254.

Higa, T. and Wididana, G.N. (1991). Changes in the soil microflora induces by effective microorganisms. Proc. $1^{\text {st }}$ Inter. Conf. Kyusei Nature Farming, U.S. Dept. Agric. Washington, D.C. p: 153-162.

Janas, R. (2009). Possibilities of using effective microorganisms in organic production systems of cultivated crops. Proplerry Inznierii Polniczei, 17(3):111119.

Kalirana, K. and Dubey, P. (2008). Effect of substrates on Anthurium culture. Asian J. Hort., 3(1):165-166.

Kobayashi, K.D. and Kaufman, A.J. (2006). Common Gardenia, Cooperative Extention Services, College of Tropical Agric. \& Human Resources, Univ. of Hawaii at Manoa.

Kramer, P.J. (1969). Soil Water Relationships, A. Modern Synthesis. McGraw Hill Book Co. New York, p. 3040.

Lambers, H.; Chapin, F.S. and Pons, T.L. (2000). Plant Physiology \& Ecology. Springer-Verlag, New York Inc., U.S.A.

Little, I.M. and Hills, F.J. (1978). Agricultural Experimentation, Design and Analysis. John Wiley and Sons Inc., New York, U.S.A.

Marfa, L.O.; Caceres, R.; Giyuffrida, F. and Gyuerin, V. (2002). Relationships between growing media fertility, percolate composition and fertigation strategy in peat-substitute substrates used for growing ornamental shrubs. Scientia Hort., 94(3/4):309-321. 
Mengel, K and Kirkby, A. (1987). Principles of Plant Nutrition. $4^{\text {th }}$ edit. International Potash Institute, Bern, Switzerland.

Mousa, G.T.; Abdul-Hafeez, E.Y. and Ibrahim, O.H. (2015). Response of Gardenia plants grown under various growth media and ferrous sulfate application. Pakistan J. Agric. Sci., 52(3): 651-658.

Primavesi, A.M. (1999). Determination of plant health by their magnetic emanation and its improvement with EM. $5^{\text {th }}$ Inter. Conf. on Kyusei Nature Farming Banghkok, Thailad, 219-225.

Romualad, G. and Tomasz, K. (2010). Effect of effective microorganisms (E.M.) on nutrient contents in substrate and development and yielding of rose (Rosa hybrida) and gerbera (Gerbera Jamesonii). Ecol. Chem. and Engineering, 17(4):505-513.

Saleh, S.I. (2000). Effect of differenting media on the growth chemical composition of Ficus benjamina
"Stralight" plants grown under two locations (outdoor and plastic house) conditions. Egypt. J. Hort., 27(4):543568.

Sayed, I.H. (2004). Response of Gladiolus Plants to Some Bio- and Chemical Fertilization. Ph.D. Thesis, Fac. Agric., Minia Univ.

Thach, N.Q.; Long, C.A.; Liet, V.; Trung, N.V.; Thanh, N.X.; Dich, T.V.; Duong, N.; Tuan, N.K.; Xuan, L.T.H. and Dar. P.V. (1999). Preliminary results of EM application in Vietnam, $5^{\text {th }}$ Inter. Conf. On Kyusei Nature Farming. Pangkok, Thailand, 23: 254-260.

Varhagen, J.B. (2004). Effectiveness of clay in peat-based growing media. Acta Hort., 644:115-122.

Yukun, X.; Yang, S.X.; YaNing, L.; Jia, T.; Meliling, J.; Xiao Qiang, G. and Wenyu, L. (2014). Effects of compost with different exogenous additives on growth of Gazania Sunshine J. of Henan Agric. Sci., 43(10):87-91.

$$
\begin{aligned}
& \text { تأثير بيئات النمو ومعاملات التسميد على النمو والتزهير لتباتات الجارينيا }
\end{aligned}
$$

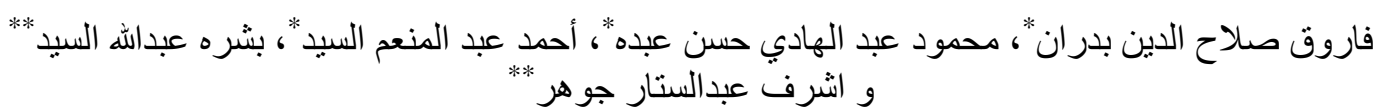

$$
\begin{aligned}
& \text { * كلية الزر اعة، جامعة المنيا، مصر. } \\
& \text { ***م بحوث الزينة وتنسيق الحدائق، معهد بحوث البسانين، مركز البحوث مصرث الزر اعية، الجيزة، مصر. }
\end{aligned}
$$

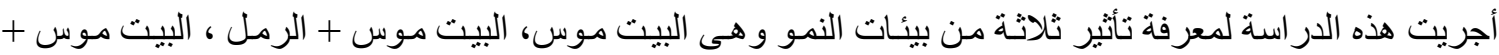

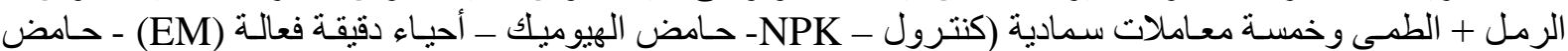

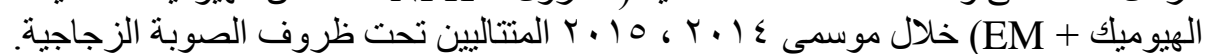

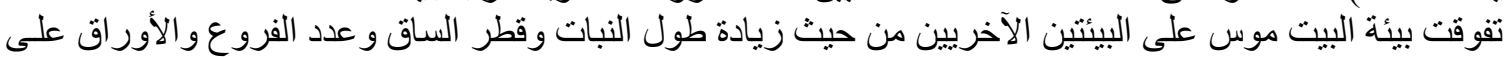

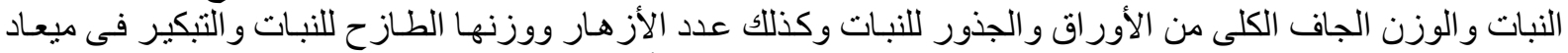

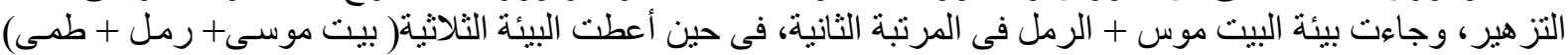

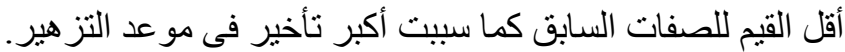

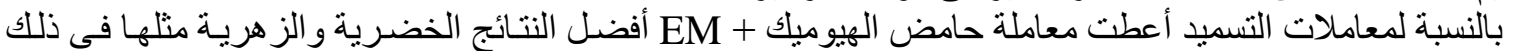

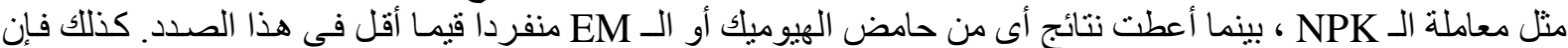

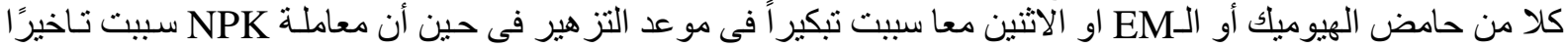

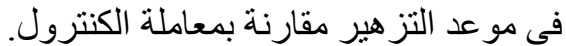

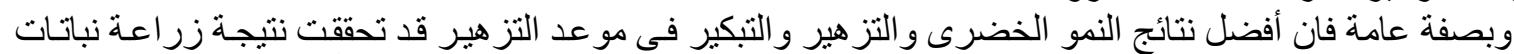

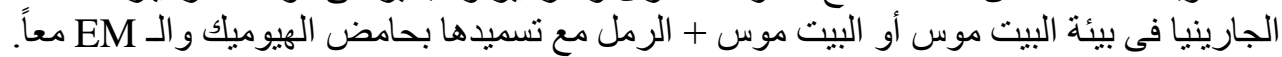


